\title{
B7-H1 and B7-H3 are independent predictors of poor prognosis in patients with non-small cell lung cancer
}

\author{
Yixiang Mao ${ }^{1, *}$, Wei Li ${ }^{1, *}$, Kai Chen ${ }^{1}$, Yufeng Xie ${ }^{1}$, Qiang Liu ${ }^{2}$, Min Yao ${ }^{3}$, Weiming \\ Duan ${ }^{1}$, Xiumin Zhou ${ }^{1}$, Rongrui Liang ${ }^{1}$ and Min Tao ${ }^{1,4}$ \\ ${ }^{1}$ Department of Oncology, the First Affiliated Hospital of Soochow University, Suzhou, China \\ ${ }^{2}$ Department of Pathology, Renji Hospital, Shanghai Jiaotong University School of Medicine, Shanghai, China \\ ${ }^{3}$ Department of Pathology, Punan Hospital, Shanghai, China \\ 4 Jiangsu Institute of Clinical Immunology, Suzhou, China \\ * These authors contributed equally to this work \\ Correspondence to: Min Tao, email:mtao@medmail.com.cn
}

Keywords: B7-H1, B7-H3, non-small cell lung cancer, prognosis

Received: November19, $2014 \quad$ Accepted: December 25, $2014 \quad$ Published: December 31, 2014

This is an open-access article distributed under the terms of the Creative Commons Attribution License, which permits unrestricted use, distribution, and reproduction in any medium, provided the original author and source are credited.

\section{ABSTRACT}

B7-H1 and B7-H3, two members of the B7 family that are thought to regulate T-cell activation, are expressed in human non-small cell lung cancer (NSCLC). However, their prognostic significance is poorly understood. In the present study we reported that B7-H1 and B7-H3 were expressed in 96/128 (72.7\%) and 89/128 $(69.5 \%)$ samples, respectively. B7-H1 and B7-H3 expression and the number of infiltrating $\mathrm{T}$-cell intracellular antigen-1+ and interferon- $\mathrm{y}+$ cells in NSCLC tissues were significantly higher than those in the adjacent tissues $(p<0.01)$. High B7-H1 or B7-H3 expression was associated with lymph node metastasis and TNM stage ( $p<0.05$, respectively). Sex, TNM stage, B7-H1, B7-H3, and T-cell intracellular antigen-1 expression remained significant prognostic factors after adjusting for other prognostic factors in a multivariate Cox proportional hazards regression model. In vitro studies revealed that knockdown of B7-H3 on tumor cells enhanced T-cell growth and interferon-y secretion when stimulated by anti-CD3 and anti-CD28 monoclonal antibodies. Interferon- $y$ reduced $C X C R 4$ expression on cancer cells and inhibited the CXCL12-induced cell migration.B7-H1 and B7-H3 are independent predictors of poorer survival in patients with NSCLC. Interference of the signal pathways of these negative regulatory molecules might be a new strategy for treating NSCLC.

\section{INTRODUCTION}

Non-small cell lung cancer (NSCLC) accounts for $80 \%-85 \%$ of all lung cancer cases.[1] The majority of patients present with advanced disease. Although some improvements have been made, the five-year survival rate of NSCLC $(16.6 \%)$ is still lower than many other leading cancers, such as the colon $(64.2 \%)$, breast $(89.2 \%)$ and prostate $(99.2 \%)$ cancer. Recent studies suggested that some tumors have distinct molecular characteristics that allow them to be further classified into subsets of disease beyond the histologic level.[2] By focusing on cancerspecific molecular changes, targeted cancer therapies may be more effective than other traditional treatments, such as chemotherapy and radiotherapy, and less harmful to normal cells.[3]

Immune evasion is now recognized as a key feature of cancer progression.[4] Interactions among subsets of immune cells through costimulatory ligands and their receptors are essential for the initiation of an immune response. The lack of CD80 and CD86 expression on tumor cells is one of the mechanisms of the immune evasion of tumor cells.[5, 6] B7-H1 (PD-L1) and B7H3, two novel members of B7/CD28 superfamily, complicate the immune response by adjusting the effects of costimulation on T-cells.[7, 8] B7-H1 is abundant on tumor cell lines and tumor tissues, and cancer cells expressing B7-H1 have been shown to increase apoptosis 
of antigen-specific human T-cell clones[4] and to inhibit $\mathrm{CD}^{+}$and $\mathrm{CD} 8^{+} \mathrm{T}$-cell activation in vitro.[9] In addition, tumor cells transfected with B7-H1 were shown to grow even after adoptive T-cell immunotherapy, whereas blockade of PD-1/B7-H1 inhibited tumorigenesis in vivo. $[10,11] \mathrm{B} 7-\mathrm{H} 3$, whose receptors have not yet been identified, is believed to be involved in both costimulatory and co-inhibitory pathways.[12] B7-H3 has been regarded as a positive regulation molecule as it was shown to stimulate $\mathrm{CD}^{+}$and $\mathrm{CD}^{+} \mathrm{T}$ cells to increase the activity of cytotoxic T lymphocytes.[13] However, further studies revealed that $\mathrm{B} 7-\mathrm{H} 3$ could also inhibit the proliferation of T cells in vitro and reduce the secretion of interferon- $\gamma$ (IFN- $\gamma$ ), tumor necrosis factor- $\alpha$, granulocyte macrophage colony-stimulating factor, and other cytokines.

Prolonged survival has associated with a large number of tumor-infiltrating lymphocytes (TILs) in cancer, measured by the infiltration of $\mathrm{CD}^{+} \mathrm{T}$ cells [14], $\mathrm{CD}^{+} \mathrm{T}$ cells [15] or $\mathrm{CD} 57^{+} \mathrm{NK}$ cells. [16] Recent studies found that cytotoxic granule-associated RNA binding protein (TIA-1) was a good marker to detect cytotoxic cells, which coded for an integral membrane protein in cytotoxic granules, mainly in cytotoxic $\mathrm{CD}^{+} \mathrm{T}$ cells (CTLs, regardless of their activation state) and NK cells. [17] Tumor cells, which express a relatively restricted repertoire of chemokine and chemokine receptors, utilize and manipulate the chemokine system in a manner that benefits both local tumor growth and distant dissemination. Among the 19 chemokine receptors, CXCR4 is the receptor most widely expressed by malignant tumors and whose role in tumor biology is most thoroughly studied. [18] The functional expression of CXCR4 induces lung cancer cell migration and adhesion to stromal cells when binding to its unique ligand stromal cell-derived factor-1 (SDF-1), which in turn provides growth- and drugresistance signals to tumor cells. CXCR4 antagonists, such as Plerixafor (AMD3100) and T140 analogues (TN14003/ BKT140), can disrupt CXCR4-mediated tumor cell adhesion to stromal cells and sensitize lung cancer cells to cytotoxic drugs.[19] Study in head and neck squamous cell carcinoma showed that IFN- $\gamma$ could also significantly reduce the expression of CXCR4.[20]

Although $\mathrm{B} 7-\mathrm{H} 1$ and $\mathrm{B} 7-\mathrm{H} 3$ was reported to express in cancer, their expression in NSCLC has not been fully characterized. Therefore, we sought to investigate their expression in NSCLC samples. In the present study, we evaluated $\mathrm{B} 7-\mathrm{H} 1$ and $\mathrm{B} 7-\mathrm{H} 3$ expression in NSCLC tissues via immunohistochemical analysis to determine the relationship between their expression and other clinicopathologic variables and their value in prognosis. We also assessed the association between B7$\mathrm{H} 1$ and B7-H3 expression on tumor cells and TIA-1 and IFN- $\gamma$ expression on TILs. The biological effects and their mechanisms of tumor-associated B7-H3 on T-cell proliferation and tumor cell migration were also explored.

\section{RESULTS}

\section{B7-H1 and B7-H3 expression in NSCLC tissues}

Staining for B7-H1 was observed in the cell cytoplasm and membrane in both cancerous and noncancerous cells. However, staining for B7-H3 was only found in cancerous cells. B7-H1 was more commonly expressed in NSCLC tissues (93/128 cases, 72.7\%) than in adjacent normal tissues (12/128 cases, 30\%; $\mathrm{p}<$ 0.01; Figure 1). Similarly, B7-H3 was more commonly expressed in NSCLC tissues (89/128 cases, 69.5\%) than in adjacent tissues $(0 / 128$ cases, $0 \%$; $<0.01$; Figure 1$)$.

\section{Relationship between B7-H1 and B7-H3 expression and clinicopathologic parameters}

The relationship between tumor cell B7-H1/ B7-H3 expression and clinicopathologic parameters was shown in Table 1. B7-H1/B7-H3 expression in NSCLC tissue samples was associated with lymph node metastasis and advanced TNM stage ( $<<0.05$ for both). Expression of either protein was not associated with sex, histopathologic type, or histologic grade. We also found a positive correlation between B7-H1 expression and B7H3 expression in NSCLC tissue samples $(p<0.05)$. Coexpression of B7-H1 and B7-H3 was observed in 68/128 (53.1\%) NSCLC tissue samples but not in adjacent tissues. Furthermore, B7-H1 and B7-H3 co-expression was much more common in patients with lymph node metastasis $(72.9 \%)$ than in those without lymph node metastasis $(29.3 \% ; \mathrm{p}<0.01)$. The proportion of samples in which B7-H1 and B7-H3 were co-expressed increased as TNM stage (I, II, or III) increased $(26.7 \%, 53.5 \%$, and $82.5 \%$, respectively; $\mathrm{p}<0.01)$. The co-expression of $\mathrm{B} 7-\mathrm{H} 1$ and B7-H3 was not significantly associated with age, sex, histopathologic type, histologic grade, and tumor size. (Table 1)

\section{Relationship between TIA-1, IFN- $\gamma$, and CXCR4 expression and clinicopathologic parameters}

The rates of TIA- $1^{+}$and IFN- $\gamma^{+}$cell high infiltration (47.7\% and $35.9 \%$, respectively) in NSCLC tissues were significantly higher than those in adjacent tissues $(\mathrm{p}<0.01$, respectively). The infiltration levels of TIA $-1^{+}$and IFN- $\gamma^{+}$ cells in NSCLC tissues decreased in the presence of lymph node metastasis and as the TNM pathologic stage increased $\left(\mathrm{p}<0.05\right.$, respectively), but the rate of TIA $-1^{+}$ cell high infiltration in squamous cell carcinomas $(57.4 \%)$ was obviously higher than that in adenocarcinomas $(38.8 \% ; p=0.04)$. The overexpression $(55.5 \%)$ of CXCR4 in NSCLC tissues was significantly higher than that in the 
Table 1: Relationship between clinicopathologic parameters and B7-H1, B7-H3, TIA-1, IFN- $\gamma$, and CXCR4 expression in $\operatorname{NSCLC~}(\mathbf{n}=128)$

\begin{tabular}{|c|c|c|c|c|c|c|c|c|c|c|c|c|c|c|c|c|}
\hline \multirow{2}{*}{ Clinicopathologic parameters } & \multirow{2}{*}{ No. of patients } & \multicolumn{2}{|c|}{ B7-H1 expression } & \multirow{2}{*}{ p value } & \multicolumn{2}{|c|}{ B7-H3 expression } & \multirow{2}{*}{$\mathrm{p}$ value } & \multicolumn{2}{|c|}{ TIA-1 $^{+}$expression } & \multirow{2}{*}{ p value } & \multicolumn{2}{|c|}{ IFN- $\gamma^{+}$expression } & \multirow{2}{*}{$\mathrm{p}$ value } & \multicolumn{2}{|c|}{ CXCR4 expression } & \multirow{2}{*}{ p value } \\
\hline & & Negative & Positive & & Negative & Positive & & Low & High & & Low & High & & Negative & Positive & \\
\hline \multicolumn{17}{|l|}{ Age at diagnosis (years) } \\
\hline$\leq 60$ & 51 & 17 & 34 & 0.22 & 10 & 41 & $0.03^{\text {* }}$ & 32 & 19 & 0.06 & 31 & 20 & 0.53 & 16 & 35 & $0.02^{*}$ \\
\hline$>60$ & 77 & 18 & 59 & & 29 & 48 & & 35 & 42 & & 51 & 26 & & 41 & 36 & \\
\hline \multicolumn{17}{|l|}{ Sex } \\
\hline Male & 91 & 21 & 70 & 0.09 & 30 & 61 & 0.34 & 42 & 49 & $0.03^{*}$ & 57 & 34 & 0.60 & 42 & 49 & 0.56 \\
\hline Female & 37 & 14 & 23 & & 9 & 28 & & 25 & 12 & & 25 & 12 & & 15 & 22 & \\
\hline \multicolumn{17}{|l|}{ Histopathologic type } \\
\hline Squamous cell carcinoma & 61 & 16 & 45 & 0.79 & 23 & 38 & 0.09 & 26 & 35 & $0.04^{*}$ & 37 & 24 & 0.45 & 30 & 31 & 0.31 \\
\hline Adenocarcinoma & 67 & 19 & 48 & & 16 & 51 & & 41 & 26 & & 45 & 22 & & 27 & 40 & \\
\hline \multicolumn{17}{|l|}{ Differentiation } \\
\hline Poor & 45 & 10 & 35 & 0.34 & 12 & 33 & 0.73 & 23 & 22 & 0.49 & 32 & 13 & 0.25 & 18 & 27 & 0.54 \\
\hline Moderate & 22 & 7 & 15 & & 6 & 16 & & 14 & 8 & & 13 & 9 & & 10 & 12 & \\
\hline Well & 61 & 18 & 43 & & 21 & 40 & & 30 & 31 & & 37 & 24 & & 29 & 32 & \\
\hline \multicolumn{17}{|l|}{ Tumor size } \\
\hline$\leq 3 \mathrm{~cm}$ & 38 & 13 & 25 & $0.04^{*}$ & 12 & 26 & 0.59 & 18 & 20 & 0.34 & 24 & 14 & 0.93 & 15 & 23 & 0.63 \\
\hline$>3 \mathrm{~cm} \leq 7 \mathrm{~cm}$ & 65 & 20 & 45 & & 21 & 44 & & 34 & 31 & & 42 & 23 & & 31 & 34 & \\
\hline$>7 \mathrm{~cm}$ & 25 & 2 & 23 & & 6 & 19 & & 15 & 10 & & 16 & 9 & & 11 & 14 & \\
\hline $\mathrm{N}_{1}$ & 70 & 14 & 56 & & 8 & 62 & & 44 & 26 & & 51 & 19 & & 27 & 43 & \\
\hline \multicolumn{17}{|l|}{ TNM stage } \\
\hline I & 45 & 15 & 30 & $0.04 *$ & 28 & 17 & $<0.01^{*}$ & 12 & 33 & $<0.01^{*}$ & 23 & 22 & $<0.01 *$ & 23 & 22 & 0.01 * \\
\hline II & 43 & 15 & 28 & & 8 & 35 & & 20 & 23 & & 25 & 18 & & 26 & 17 & \\
\hline III & 40 & 5 & 35 & & 3 & 37 & & 35 & 5 & & 34 & 6 & & 8 & 32 & \\
\hline
\end{tabular}

adjacent tissues $(\mathrm{p}<0.01)$. CXCR4 was only minimally expressed in the adjacent tissues. CXCR4 expression increased as the TNM pathologic stage increased $(\mathrm{p}=0.01)$. (Table 1)

In NSCLC tissues, B7-H3 expression was positively correlated with $\mathrm{CXCR} 4$ expression $(\mathrm{r}=0.36 ; \mathrm{p}<0.01)$. The high infiltration rate of TIA- $1^{+}$cells was positively associated with the high infiltration rate of IFN- $\gamma^{+}$cells $(\mathrm{r}=0.28 ; \mathrm{p}<0.01)$.

\section{Relationship between B7-H1 and B7-H3 expression and $\mathrm{OS}$}

At the time of the final follow-up, 85 of 128 patients had died; of the remaining 43, 42 were alive and 1 was lost to follow-up. Patients whose tumors were positive for B7$\mathrm{H} 1$ had shorter OS times than those whose tumors were negative for B7-H1 (28.7 months vs 60.6 months; $\mathrm{p}<0.01$ ). Other prognostic factors were also shown to negatively affect OS, including B7-H3 (25.0 months vs 60.6 months; $\mathrm{p}<0.01)$ and CXCR4 expression $(28.7$ months vs 40.7 months; $p=0.08$ ). Patients whose tumors were negative for both $\mathrm{B} 7-\mathrm{H} 1$ and $\mathrm{B} 7-\mathrm{H} 3$ had the best prognosis (60.6 months), whereas those with tumors in which both B7$\mathrm{H} 1$ and $\mathrm{B} 7-\mathrm{H} 3$ were expressed had the poorest prognosis (22.7 months). NSCLC patients with high infiltration rates of TIA- $1^{+}$or IFN- $\gamma^{+}$cells had a better prognosis than those with low infiltration rates.(Table 2) After adjusting for sex, tumor differentiation, tumor size, lymph node metastasis, TNM stage, and expression of B7-H1, B7-H3, TIA- $1^{+}$, IFN- $\gamma^{+}$, and CXCR4, patients whose tumors were positive for B7-H1 (HR, 1.90; 95\% CI, 1.09-3.30; $\mathrm{p}=0.02)$ or B7-H3 (HR, 2.26; 95\% CI, 1.21-4.23; $\mathrm{p}=0.01$ ) were at an increased risk of death (Table 3 ). In addition, patients who were male, had advanced TNM stage disease, or had low infiltration of TIA- $1^{+}$in their tumors were also at an increased risk of death ( $\mathrm{p}<0.05$ for both).

\section{B7-H3 expression on lung cancer cell lines and its association with metastasis}

B7-H3 was highly expressed on lung cancer H1299 cells. The B7-H3 gene silencing on H1299 cells promoted the proliferation of T-cells and stimulated these cells to secrete IFN- $\gamma$ with the costimulation by anti-CD3 mAb
A

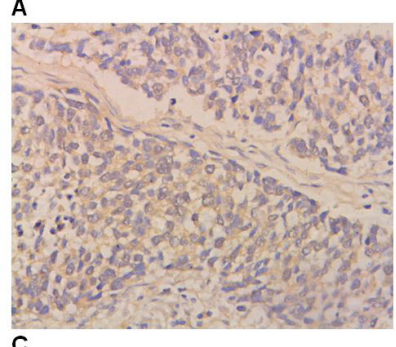

C

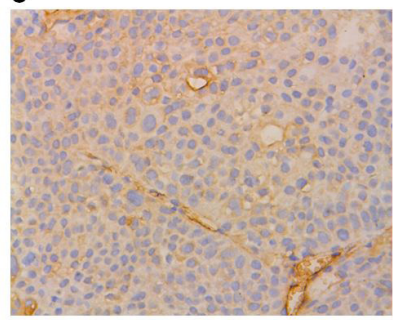

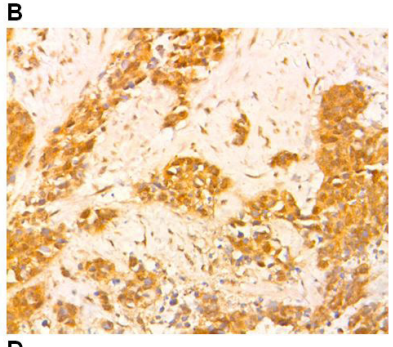

D

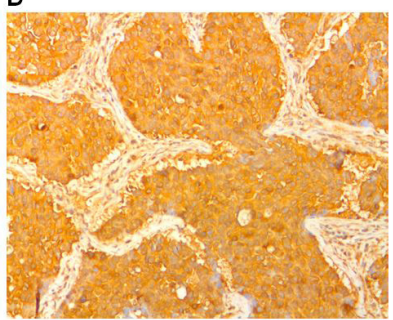

Figure 1: Immunohistochemical staining showing B7-H1 and B7-H3 expression in NSCLC and normal lung tissues (original magnification $\times \mathbf{1 0 0}$ ). (A) Negative cytoplasmic expression of B7-H1 (B) Positive cytoplasmic expression of B7-H1 (C) Negative cytoplasmic expression of B7-H3 (D) Positive cytoplasmic expression of B7-H3. 
Table 2: Correlation between molecular markers and median OS in NSCLC patients (univariate analysis)

\begin{tabular}{|c|c|c|c|}
\hline Molecular markers & Cases (n) & MST (months) & Log-rank p value \\
\hline \multicolumn{4}{|l|}{ B7-H1 } \\
\hline negative & 35 & 60.6 & $<0.01 *$ \\
\hline positive & 93 & 28.7 & \\
\hline \multicolumn{4}{|l|}{ B7-H3 } \\
\hline negative & 39 & 60.6 & $<0.01 *$ \\
\hline positive & 89 & 25.0 & \\
\hline \multicolumn{4}{|l|}{ TIA-1 $^{+}$} \\
\hline low infiltration & 67 & 20.5 & $<0.01 *$ \\
\hline high infiltration & 61 & 59.2 & \\
\hline \multicolumn{4}{|l|}{ IFN $-\gamma^{+}$} \\
\hline low infiltration & 82 & 28.7 & $0.02 *$ \\
\hline high infiltration & 46 & 44.7 & \\
\hline \multicolumn{4}{|l|}{ CXCR4 } \\
\hline negative & 57 & 40.7 & 0.08 \\
\hline positive & 71 & 28.7 & \\
\hline \multicolumn{4}{|l|}{ В7-H1/B7-H3 } \\
\hline B7-H1-/B7-H3- & 14 & 60.6 & $<0.01 *$ \\
\hline B7-H1-/B7-H3+ & 21 & 37.1 & \\
\hline B7-H1+/B7-H3- & 25 & 49.5 & \\
\hline B $7-\mathrm{H} 1+/ \mathrm{B} 7-\mathrm{H} 3+$ & 68 & 22.7 & \\
\hline
\end{tabular}

${ }^{*} \mathrm{p}<0.05$; MST, median survival time

A

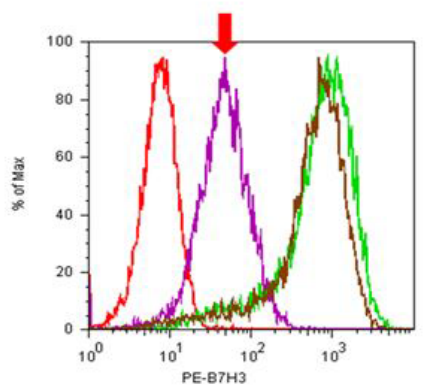

C

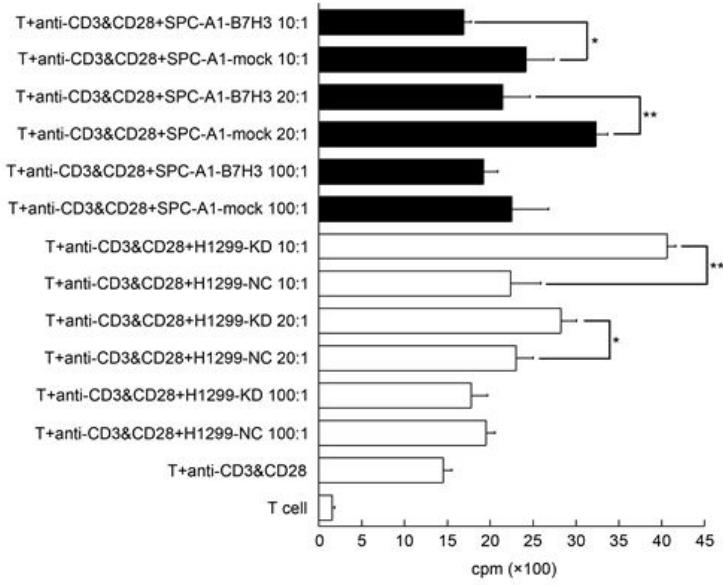

B

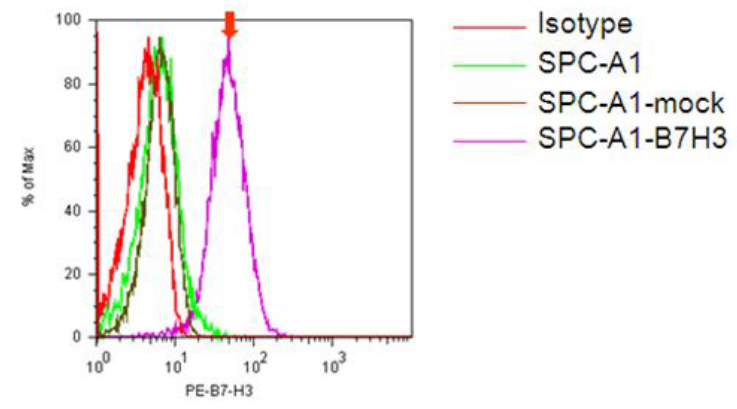

D

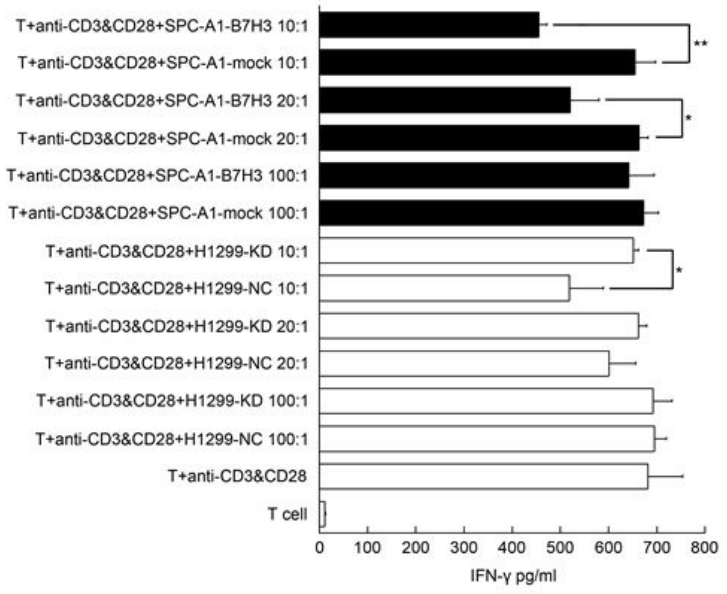

Figure 2: Effects of $\mathrm{B} 7-\mathrm{H} 3$ expression on T-cell proliferation and IFN- $\gamma$ secretion (1) $\mathrm{B} 7-\mathrm{H} 3$ expression of on cell membrane of H1299. (A) and SPC-A1 (B) cells (2) T-cell proliferation (C) and IFN- $\gamma$ secretion (D) stimulated by B7-H3 silencing or transfected cells $\left({ }^{*} \mathrm{p}<0.05 ; * * \mathrm{p}<0.001\right)$ H1299-NC, vector-transfected H1299 cells; H1299-KD, B7-H3 knockdown H1299 cells; SPCA1-mock, vector-transfected SPC-A1 cells; SPC-A1-B7-H3, B7-H3-transfected SPC-A1 cells. Experiments were done in triplicate and average \pm SE displayed. 
Table 3: Correlation between clinicopathologic parameters and median OS in NSCLC patients (multivariate analysis)

\begin{tabular}{lccc}
\hline \multicolumn{1}{c}{ Clinicopathologic parameters } & HR & $\mathbf{9 5 . 0 \%}$ CI & p value \\
\hline Sex & 0.52 & $0.30-0.90$ & $0.02^{*}$ \\
Tumor differentiation & 0.74 & $0.52-1.06$ & 0.10 \\
Tumor size & 0.85 & $0.63-1.16$ & 0.31 \\
Lymph node metastasis & 0.92 & $0.42-2.01$ & 0.84 \\
TNM stage & 1.82 & $1.05-3.16$ & $0.03^{*}$ \\
B7-H1 & 1.90 & $1.09-3.30$ & $0.02^{*}$ \\
B7-H3 & 2.26 & $1.21-4.23$ & $0.01^{*}$ \\
TIA-1 & \\
IFN- $^{+}$ & 0.32 & $0.16-0.63$ & $<0.01^{+}$ \\
CXCR4 $^{+}$ & 1.45 & $0.78-2.67$ & 0.24 \\
\hline
\end{tabular}

$* \mathrm{p}<0.05 ; \mathrm{HR}$, hazard ratio; CI, confidence interval.

and anti-CD28 mAb in vitro $(\mathrm{p}<0.05)$. (Figure2) It also showed that IFN- $\gamma$ reduced CXCR4 expression on H1299 cells by both flow cytometry and RT $\neg$-PCR. (Figure 3A and B) Like AMD3100 (a CXCR4 antagonist), IFN- $\gamma$ significantly inhibited the migration capacity of H1299 cells stimulated by CXCL12 ( $<<0.01$ ) (Figure 3 C). In vitro scratch assay revealed that the knockdown of $\mathrm{B} 7-$ $\mathrm{H} 3$ on H1299 cells slowed the migration of cells toward the scratch. (Figure 4) However, when B7-H3 gene was transfected to B7-H3 low expressed lung cancer SPC-A1 cells, we found a significantly inhibition of proliferation and IFN- $\gamma$ secretion of T-cells $(\mathrm{p}<0.05)$. (Figures 2)

\section{DISCUSSION}

Our results revealed cytoplasmic and membrane expression of $\mathrm{B} 7-\mathrm{H} 1$ and $\mathrm{B} 7-\mathrm{H} 3$ in surgically resected NSCLC specimens. The expression patterns of these molecules were consistent with those reported in previous studies that examined their expression in human tumor tissue. $[4,9,10,21]$ B7-H1 and B7-H3 were more likely to be expressed in NSCLC cells than in normal lung
A

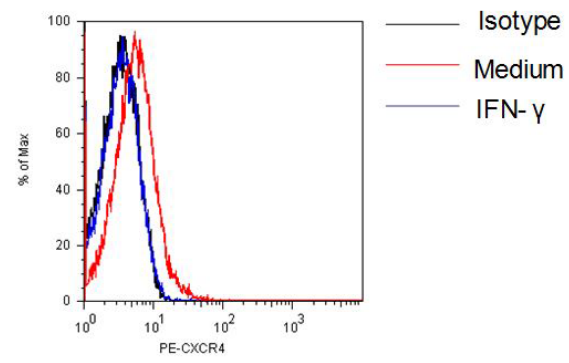

B

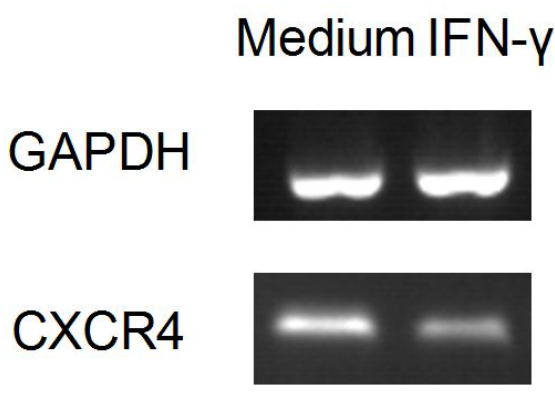

C

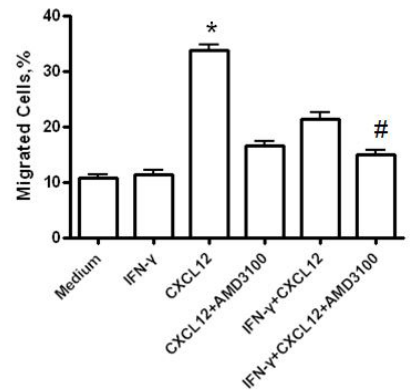

Figure 3: H1299 cell migration induced by IFN- $\gamma$ after 72 hours. (A) CXCR4 expression by flow cytometry; (B) CXCR4 expression by RT-PCR; (C) Migration ability of H1299 cells before and after IFN- $\gamma$ stimulation ( ${ }^{*} \mathrm{p}<0.001$, compared with all other groups; ${ }^{*} \mathrm{p}<0.01$, compared with the IFN $-\gamma+\mathrm{CXCL} 12$ group) Experiments were done in triplicate and average \pm SE displayed. 
tissues, and B7-H1/B7-H3 expression was associated with decreased OS in patients with NSCLC. Thus, B7H1/B7-H3 expression in NSCLC tissues could be a useful independent predictor of prognosis. Biological studies showed that B7-H3 was a negative regulatory molecule, as it inhibited T-cell proliferation and promoted tumor cell migration.

Accumulating evidence [22] has indicated that B7 family molecules are widely expressed in NSCLC and that their interactions with corresponding receptors are directly related to T-cell engagement of antigens. Previous studies revealed low expression of $\mathrm{B} 7-\mathrm{H} 1$ and high expression of B7-H3 in NSCLC. B7-H1 and B7-H3 expression was associated with a decreased number of TILs. [23-25] However, a recent study by Boland et al. did not reveal an association with $\mathrm{B} 7-\mathrm{H} 1$ or $\mathrm{B} 7-\mathrm{H} 3$ expression and the number of TILs in squamous cell lung carcinoma. Our study showed that B7-H1 and B7-H3 expression and the number of infiltrating TIA- $1^{+}$and IFN- $\gamma^{+}$cells in NSCLC tissues were significantly higher than those in the adjacent tissues. Statistical analysis revealed that high B7-H1 or B7-H3 expression was associated with lymph node metastasis $(p<0.05)$ and TNM stage $(p<0.05)$.

Only one study showed B7-H1 expression in NSCLC positivity correlated with survival shorter than 3 years after lobectomy[23, 26, 27], and the findings of studies of B7-H3 and survival were controversial. Xu et al. [24] reported that low B7-H3 expression was associated with poor prognosis in NSCLC, whereas, Bonald et al. [27] found no association between B7-H3 expression and poorer survival in squamous cell carcinoma of the lung. In this study, we found that B7-H1, B7-H3, and TIA-1 expression remained significant prognostic factors after adjusting for other prognostic factors in a multivariate

H1299-NC

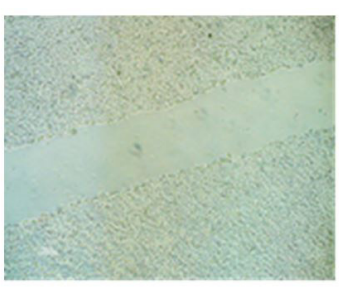

$24 \mathrm{~h}$

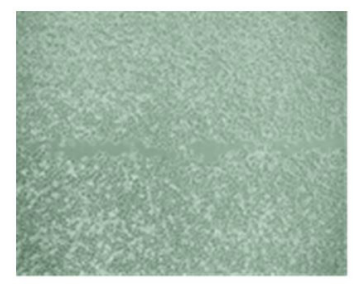

Figure 4: Migration capacity of H1299-KD and H1299NC cells H1299-NC cells covered with scratches after 24 hours of incubation, whereas the same phenomena were not observed on H1299-KD cells. H1299-NC, vector-transfected H1299 cells; H1299-KD, B7-H3 knockdown H1299 cells. Experiments were done in triplicate.
Cox proportional hazards regression model. It showed that B7-H1 and B7-H3 could repress the antitumor immune response in NSCLC by inhibiting the infiltration of cells that express TIA- 1 and IFN- $\gamma$. Thus, our results indicate that B7-H1 and B7-H3 expression is an independent predictor of poor prognosis in patients with NSCLC. The interference of the signal pathways of these negative regulatory molecules might be a new strategy for treating NSCLC. Our results indicate that B7-H3 has inhibitory effects on the immune system; however, the real function of B7-H3 in human NSCLC could be more complicated.

The mechanisms regulating $\mathrm{B} 7-\mathrm{H} 3$ expression on tumor cells are not well known. Previous studies suggested that the cytokine microenvironment induced the expression of $\mathrm{B} 7-\mathrm{H} 1$ on tumor cells.[23, 28] In addition, T-cells or natural killer cells that infiltrated into tumor tissue were shown to secrete IFN- $\gamma$ and some other cytokines. In the current study, decreasing IFN- $\gamma$ prompted CXCR4 expression on cancer cells, which could help tumor cells escape from immunity. These results suggest that B7-H3 may be involved in the development of human NSCLC.

One limitation of our study was the relatively small sample, which could lead to an overestimation of the magnitude of relationships between variables. Our patients had stage I-III disease and received various kinds of therapy, which may have introduced treatment bias. Nonetheless, our findings suggest that B7-H1 and B7H3 play an important role in tumor metastasis and thus could be applied as prognostic markers and/or targets for NSCLC therapy. Further investigations are necessary to clarify and understand the role of B7-H1 and B7-H3 in patients with NSCLC.

\section{MATERIALS AND METHODS}

\section{Tissue samples}

Primary tumor samples and clinical data were obtained from 128 patients with NSCLC who underwent surgery without any preoperative therapy (91 men and 37 women; median age at diagnosis, 62.5 years) between March 2005 and October 2007 at the First Affiliated Hospital of Soochow University and Shanghai Renji Hospital in China. NSCLC stage was classified according to the AJCC tumor-node-metastasis (TNM) staging system (2002 version).[29] Cell differentiation was determined using the World Health Organization (WHO) classification (2000 revision).[30] Data on patients' age, sex, tumor location, histopathologic type, histologic grade, tumor size, lymph node invasion, and tumor stage were extracted from medical records. The median follow-up time was 53.3 months (range, 40.3-74.0 months), and the most recent follow-up correspondence was initiated on 
March 31, 2011. The study was conducted after informed consent was obtained from all patients and approval from an independent research ethics committee.

\section{Cell lines}

Lung cancer cell lines H1299 (HLA-A*0201-) and SPC-A1 (HLA-A* $0201^{-}$) were form Institute of Health Sciences, Shanghai Institutes for Biological Sciences, Chinese Academy of Sciences and maintained in RPMI1640 medium supplemented with $10 \%$ fetal calf serum.

\section{Immunohistochemical analysis}

Immunostaining was performed using the EliVision plus kit (Maixin-Bio, Fuzhou, China). Formalin-fixed, paraffin-embedded tissue blocks were sectioned to $3 \mu \mathrm{m}$ and mounted on charged glass slides (Fisher Scientific, Pittsburgh, PA). Antigen retrieval was done in a citrate buffer $[20 \mathrm{mmol} / \mathrm{L}(\mathrm{pH} 6.0)]$ at $120^{\circ} \mathrm{C}$ for 10 minutes. Endogenous peroxidase activity was blocked with $3.0 \%$ hydrogen peroxide for 10 minutes. Mouse antihuman B7-H1 monoclonal antibody $(\mathrm{mAb}$; diluted 1:100; Clone 2H11)[31] and mouse anti-human B7-H3 $\mathrm{mAb}$ (diluted 1:100; Clone 4H7)[32] were used as the primary antibodies, and mouse immunoglobulin $\mathrm{G}$ was used as the negative control. Mouse anti-human TIA-1 $\mathrm{mAb}$, mouse anti-human IFN- $\gamma \mathrm{mAb}$, and mouse antihuman CXCR4 mAb were purchased from Santa Cruz Biotechnology (Santa Cruz, CA) and used according to the manufacturer's instructions. For visualization, the sections were incubated with 3, 3-diaminobenzidine solution and counterstained with hematoxylin.

\section{Evaluation of immunostaining}

Histologic analysis was performed by two investigators simultaneously without knowledge of the patients' clinical characteristics. B7-H1 and B7-H3 expression was measured as the percentage of tumor cells displaying immunoreactivity in the cytoplasm or on the membrane, which was determined by counting the number of B7-H1- or B7-H3-stained tumor cells out of 1,000 tumor cells in each section. Cells were counted at $400 \times$ magnification in at least 10 fields in randomly selected tumor areas. Staining was evaluated using a semiquantitative assay previously described by Remmele et al.[33] The immunoreactive score was calculated by multiplying the staining intensity. The percentage of cells with positive staining was scored as follows: $0=$ no staining, 1 = weak staining, 2 = moderate staining, and $3=$ strong staining. The percentage of positively stained cells was scored as follows: $0=$ no staining, $1=1 \%-10 \%$ of cells, $2=11 \%-50 \%$ of cells, and $3=$ more than $50 \%$ of cells stained. The total score per sample therefore ranged from 0 to 9 whereby 0 indicated no staining (e.g., negative results), 1 indicated weak staining, 2 or 3 indicated moderate staining, and more than 3 indicated strong staining. In the final analysis, samples with no staining or weak staining were considered to have negative expression, and samples with moderate or strong staining were considered to have positive expression.

Whole areas of each section were surveyed microscopically at $40 \times$ magnification, and cells counts were performed at $400 \times$ magnification in at least five fields in randomly selected tumor areas. The density of tumoral lymphoid infiltrates was quantified by counting the small round lymphocytes distributed within the tumor epithelium and the peritumoral stroma. TIA-1-expressing TILs were scored as follows: $0=$ no staining, $1=1-25$ cells stained, $2=26-50$ cells stained, and $3=51$ or more cells stained. IFN- $\gamma$-expressing TILs were scored as follows: $0=$ no staining, $1=1-5$ cells stained, $2=6-19$ cells stained, and $3=20$ or more cells stained. Scores from 0 to 1 were considered low infiltration, whereas scores from 2 to 3 were defined as high infiltration.[34]

\section{Reverse transcriptase polymerase chain reaction}

The tumor cells were harvested and lysed in TRIzol reagent (Invitrogen, CA). First-strand cDNA was prepared using random primers and following the manufacturer's instructions for the SuperScript III First-Strand Synthesis kit (Invitrogen, CA). Synthesis of cDNA was controlled by performing reverse transcriptase polymerase chain reaction (RT-PCR) using glyceraldehyde 3-phosphate dehydrogenase primers. RT-PCR with the primers 5'- TACTCGAAGCCCAGCATGACC-3' (forward primer) and 5'- CCACCAGCAGTGCAATGAGAC-3' (reverse primer) specific for human B7-H3, the primers 5'-CTAATTATTCGGTAACTGACTTGA-3' (forward primer) and 5'-ACAGTTCAGCCATCACTTGGA-3' (reverse primer) specific for human IFN- $\gamma$, and the primers 5'- GTCGTGGAGTCTACTGGCGTCTT -3' (forward primer), 5'- CAGTCTTCTGAGTGGCAGTGATGG -3 ' (reverse primer) specific for human glyceraldehyde 3-phosphate dehydrogenase was performed using TaKaRa LA Taq enzyme (Takara, Shiga, Japan). Cycle conditions were $94^{\circ} \mathrm{C}$ for 30 seconds, $58^{\circ} \mathrm{C}$ for 30 seconds, and $72^{\circ} \mathrm{C}$ for 30 seconds for 35 cycles.

\section{Flow cytometry}

Cell surface expression was determined via immunofluorescence staining and flow cytometry with the Coulter Epics XL flow cytometer with EXPO32 software (Beckman Coulter, CA). The cells were incubated with anti-B7-H1 mAb (2H11) or anti-B7-H3 mAb (4H7) for 30 minutes at room temperature. After being washed 
thoroughly with phosphate-buffered saline (PBS), the cells were stained with phycoerythrin-conjugated goat antimouse antibodies (Immunotech, Marseille, France) for 30 minutes at $4^{\circ} \mathrm{C}$. Non-specific staining was determined using isotype control antibodies.

\section{Transfection}

SPC-A1 cells were transfected with the pIRES2EGFP plasmid containing the full-length human B7-H3 gene (SPC-A1-B7-H3) or with the wild-type pIRES2EGFP plasmid (SPC-A1-Mock) and selected on the basis of G418 resistance. B7-H3 knockdown (H1299-KD) and vector control (H1299-NC) H1299 cells were transfected with the corresponding pGPU6/GFP/Neo plasmids (GenePharma, Shanghai, China), and the expression of surface molecules was confirmed by flow cytometry using an anti-B7-H3 mAb (4H7).

\section{In vitro analysis of $\mathrm{T}$-cell responses}

For T-cell proliferation assays, 96-well flat-bottom plates were coated with $1 \mu \mathrm{g} / \mathrm{ml}$ agonist anti-CD3 and 5 $\mu \mathrm{g} / \mathrm{ml}$ anti-CD28 mAb (Immunotech, Marseille, France) in PBS at $4{ }^{\circ} \mathrm{C}$ overnight. Either mitomycin-treated tumor cells or medium alone was added to the plates cocultured with $1 \times 10^{5}$ purified T-cells obtained from peripheral blood mononuclear cells (HLA-A*0201-) at an effectorto-target ratio of $1: 10,1: 20$, and 1:100. Then, T-cells were incubated for 72 hours and pulsed with $1 \mu \mathrm{Ci}$ of $\left[{ }^{3} \mathrm{H}\right]$ thymidine. Sandwich enzyme-linked immunosorbent assay for human IFN- $\gamma$ was performed according to the manufacturer's instructions (R\&D Systems, Minneapolis, $\mathrm{MN})$.

\section{Migration assays}

Transwell migration assays were conducted on H1299 cells with natural B7-H3 gene expression. Tumor cells were pretreated with IFN- $\gamma(10 \mathrm{ng} / \mathrm{ml})$ or AMD3100 (10 $\mu \mathrm{g} / \mathrm{ml})$ for 24 hours. Transwell chambers $(8-\mu \mathrm{M}$ pore) were coated with $10 \mu \mathrm{g} / \mathrm{mL}$ fibronectin (SigmaAldrich, St. Louis, MO) and incubated overnight at $4^{\circ} \mathrm{C}$, washed in PBS, and rehydrated with serum-free media for 30 minutes at $37^{\circ} \mathrm{C}$. The media were removed, and cells $\left(1 \times 10^{5} /\right.$ chamber $)$ were added to upper chambers with $100 \mathrm{ng} / \mathrm{ml} \mathrm{CXCL12} \mathrm{in} \mathrm{lower} \mathrm{chambers} \mathrm{as} \mathrm{a}$ chemoattractant. IFN- $\gamma$ was chosen as a control. The chambers were incubated for 20 hours at $37^{\circ} \mathrm{C}$ and $5 \%$ $\mathrm{CO}_{2}$. Migrated cells on the underside of the filter were fixed in 10\% ethanol for 20 minutes prior to staining with 4,6-diamidino-2-phenylindole (Sigma-Aldrich, St. Louis, $\mathrm{MO}$ ) for 10 minutes at room temperature. Membranes were mounted on glass slides, and cells were enumerated using flow cytometry (Beckman Coulter, Brea, CA) to analyze multiple fluorescent micrographs. Results from three independent experiments with three replicates per experiment were pooled.

Scratch-wound migration assays were conducted on H1299 cells after B7-H3 gene knockdown. When cell monolayers reached $90 \%$ confluence, a scratch wound was made using a pipette tip. The closure of the wound was measured after 20 hours.

\section{Statistical analysis}

Comparisons between unpaired groups were made using the Mann-Whitney $U$ test. Correlations between the parameters were evaluated with Spearman's rank correlation test. The overall survival (OS) times of patients whose specimens did or did not have B7-H1/B7H3 expression were compared using the Kaplan-Meier method of survival analysis and the log-rank test. For all patients, survival time was calculated from the date of pathologic diagnosis of cancer to the date of death or last follow-up. The data from patients who were alive at the last day of follow-up were censored. The median followup time was calculated using only censored data. The median survival time was also calculated. Hazard ratios (HRs) and 95\% confidence intervals (CIs) were estimated using univariate and multivariate Cox proportional hazard models. All statistical testing was conducted using SPSS software, version 20.0 (Chicago, IL). p values were twosided, and $\mathrm{p}<0.05$ was considered statistically significant.

\section{ACKNOWLEDGMENTS}

We thank Markeda Wade for editing the manuscript. Supported by National Natural Science Foundation of China (No. 81272542, 81101867 and 30901765); Medical Scientific Research Project of Jiangsu Provincial Bureau of Health (No. Z201206); China International Medical Foundation (No. CIMF-F-H001-057); the Special Foundation of Wu Jieping Medical Foundation for Clinical Scientific Research (No. 320.6753.1225); Science and Education for Health Foundation of Suzhou for Youth (No. SWKQ1003); Science and Technology Project Foundation of Suzhou (No. SYS201112).

\section{REFERENCES}

1. Ramalingam S and Belani C. Systemic chemotherapy for advanced non-small cell lung cancer: recent advances and future directions. Oncologist. 2008; 13 Suppl 1:5-13.

2. Marchetti A, Martella C, Felicioni L, Barassi F, Salvatore S, Chella A, Camplese PP, Iarussi T, Mucilli F, Mezzetti A, Cuccurullo F, Sacco R and Buttitta F. EGFR mutations in non-small-cell lung cancer: analysis of a large series of cases and development of a rapid and sensitive method 
for diagnostic screening with potential implications on pharmacologic treatment. J Clin Oncol. 2005; 23(4):857865.

3. Mok TS, Wu YL, Thongprasert S, Yang CH, Chu DT, Saijo N, Sunpaweravong P, Han B, Margono B, Ichinose Y, Nishiwaki Y, Ohe Y, Yang JJ, Chewaskulyong B, Jiang H, Duffield EL, et al. Gefitinib or carboplatin-paclitaxel in pulmonary adenocarcinoma. N Engl J Med. 2009; 361(10):947-957.

4. Dong H, Strome SE, Salomao DR, Tamura H, Hirano F, Flies DB, Roche PC, Lu J, Zhu G, Tamada K, Lennon VA, Celis E and Chen L. Tumor-associated B7-H1 promotes T-cell apoptosis: a potential mechanism of immune evasion. Nat Med. 2002; 8(8):793-800.

5. Denfeld RW, Dietrich A, Wuttig C, Tanczos E, Weiss JM, Vanscheidt W, Schopf E and Simon JC. In situ expression of $\mathrm{B} 7$ and $\mathrm{CD} 28$ receptor families in human malignant melanoma: relevance for T-cell-mediated anti-tumor immunity. Int J Cancer. 1995; 62(3):259-265.

6. Wroblewski JM, Bixby DL, Borowski C and Yannelli JR. Characterization of human non-small cell lung cancer (NSCLC) cell lines for expression of MHC, co-stimulatory molecules and tumor-associated antigens. Lung Cancer. 2001; 33(2-3):181-194.

7. Dong H, Zhu G, Tamada K and Chen L. B7-H1, a third member of the B7 family, co-stimulates T-cell proliferation and interleukin-10 secretion. Nat Med. 1999; 5(12):13651369.

8. Chapoval AI, Ni J, Lau JS, Wilcox RA, Flies DB, Liu D, Dong H, Sica GL, Zhu G, Tamada K and Chen L. B7-H3: a costimulatory molecule for $\mathrm{T}$ cell activation and IFNgamma production. Nat Immunol. 2001; 2(3):269-274.

9. Wintterle S, Schreiner B, Mitsdoerffer M, Schneider D, Chen L, Meyermann R, Weller M and Wiendl H. Expression of the B7-related molecule B7-H1 by glioma cells: a potential mechanism of immune paralysis. Cancer Res. 2003; 63(21):7462-7467.

10. Strome SE, Dong H, Tamura H, Voss SG, Flies DB, Tamada K, Salomao D, Cheville J, Hirano F, Lin W, Kasperbauer JL, Ballman KV and Chen L. B7-H1 blockade augments adoptive T-cell immunotherapy for squamous cell carcinoma. Cancer Res. 2003; 63(19):6501-6505.

11. Iwai $\mathrm{Y}$, Ishida $\mathrm{M}$, Tanaka $\mathrm{Y}$, Okazaki $\mathrm{T}$, Honjo $\mathrm{T}$ and Minato N. Involvement of PD-L1 on tumor cells in the escape from host immune system and tumor immunotherapy by PD-L1 blockade. Proc Natl Acad Sci U S A. 2002; 99(19):12293-12297.

12. Collins M, Ling V and Carreno BM. The B7 family of immune-regulatory ligands. Genome Biol. 2005; 6(6):223.

13. Ling V, Wu PW, Spaulding V, Kieleczawa J, Luxenberg D, Carreno BM and Collins M. Duplication of primate and rodent B7-H3 immunoglobulin V-and C-like domains: divergent history of functional redundancy and exon loss. Genomics. 2003; 82(3):365-377.
14. Zhang L, Conejo-Garcia JR, Katsaros D, Gimotty PA, Massobrio M, Regnani G, Makrigiannakis A, Gray H, Schlienger K, Liebman MN, Rubin SC and Coukos G. Intratumoral $\mathrm{T}$ cells, recurrence, and survival in epithelial ovarian cancer. N Engl J Med. 2003; 348(3):203-213.

15. Schumacher K, Haensch W, Roefzaad C and Schlag PM. Prognostic significance of activated CD8(+) T cell infiltrations within esophageal carcinomas. Cancer Res. 2001; 61(10):3932-3936.

16. Villegas FR, Coca S, Villarrubia VG, Jimenez R, Chillon MJ, Jareno J, Zuil M and Callol L. Prognostic significance of tumor infiltrating natural killer cells subset CD57 in patients with squamous cell lung cancer. Lung Cancer. 2002; 35(1):23-28.

17. Anderson P, Nagler-Anderson C, O'Brien C, Levine H, Watkins S, Slayter HS, Blue ML and Schlossman SF. A monoclonal antibody reactive with a $15-\mathrm{kDa}$ cytoplasmic granule-associated protein defines a subpopulation of CD8+ T lymphocytes. J Immunol. 1990; 144(2):574-582.

18. Wald O, Shapira OM and Izhar U. CXCR4/CXCL12 axis in non small cell lung cancer (NSCLC) pathologic roles and therapeutic potential. Theranostics. 2013; 3(1):26-33.

19. Burger JA, Stewart DJ, Wald O and Peled A. Potential of CXCR4 antagonists for the treatment of metastatic lung cancer. Expert review of anticancer therapy. 2011; 11(4):621-630.

20. Katayama A, Ogino T, Bandoh N, Nonaka S and Harabuchi Y. Expression of CXCR4 and its down-regulation by IFNgamma in head and neck squamous cell carcinoma. Clin Cancer Res. 2005; 11(8):2937-2946.

21. Brown JA, Dorfman DM, Ma FR, Sullivan EL, Munoz O, Wood CR, Greenfield EA and Freeman GJ. Blockade of programmed death-1 ligands on dendritic cells enhances $\mathrm{T}$ cell activation and cytokine production. J Immunol. 2003; 170(3):1257-1266.

22. Nomi T, Sho M, Akahori T, Hamada K, Kubo A, Kanehiro H, Nakamura S, Enomoto K, Yagita H, Azuma M and Nakajima Y. Clinical significance and therapeutic potential of the programmed death-1 ligand/programmed death-1 pathway in human pancreatic cancer. Clin Cancer Res. 2007; 13(7):2151-2157.

23. Konishi J, Yamazaki K, Azuma M, Kinoshita I, DosakaAkita H and Nishimura M. B7-H1 expression on non-small cell lung cancer cells and its relationship with tumorinfiltrating lymphocytes and their PD-1 expression. Clin Cancer Res. 2004; 10(15):5094-5100.

24. Xu YH, Zhang GB, Wang JM and Hu HC. B7-H3 and CD133 expression in non-small cell lung cancer and correlation with clinicopathologic factors and prognosis. Saudi Med J. 2010; 31(9):980-986.

25. Sun Y, Wang Y, Zhao J, Gu M, Giscombe R, Lefvert AK and Wang X. B7-H3 and B7-H4 expression in non-smallcell lung cancer. Lung Cancer. 2006; 53(2):143-151.

26. Mu CY, Huang JA, Chen Y, Chen $\mathrm{C}$ and Zhang XG. High 
expression of PD-L1 in lung cancer may contribute to poor prognosis and tumor cells immune escape through suppressing tumor infiltrating dendritic cells maturation. Med Oncol. 2011; 28(3):682-688.

27. Boland JM, Kwon ED, Harrington SM, Wampfler JA, Tang H, Yang P and Aubry MC. Tumor B7-H1 and B7-H3 Expression in Squamous Cell Carcinoma of the Lung. Clin Lung Cancer. 2012.

28. Sznol M and Chen L. Antagonist Antibodies to PD-1 and B7-H1 (PD-L1) in the Treatment of Advanced Human Cancer. Clin Cancer Res. 2013; 19(5):1021-1034.

29. Greene FL, American Joint Committee on Cancer. and American Cancer Society. (2002). AJCC cancer staging manual. (New York: Springer).

30. Aaltonen LA, Hamilton SR, World Health Organization. and International Agency for Research on Cancer. (2000). Pathology and genetics of tumours of the digestive system. (Lyon Oxford: IARC Press ; Oxford University Press (distributor).

31. Zhou YH, Chen YJ, Ma ZY, Xu L, Wang Q, Zhang GB, Xie F, Ge Y, Wang XF and Zhang XG. 4IgB7-H3 is the major isoform expressed on immunocytes as well as malignant cells. Tissue Antigens. 2007; 70(2):96-104.

32. Sun J, Chen LJ, Zhang GB, Jiang JT, Zhu M, Tan Y, Wang HT, Lu BF and Zhang XG. Clinical significance and regulation of the costimulatory molecule $\mathrm{B} 7-\mathrm{H} 3$ in human colorectal carcinoma. Cancer Immunol Immunother. 2010; 59(8):1163-1171.

33. Remmele W and Stegner HE. [Recommendation for uniform definition of an immunoreactive score (IRS) for immunohistochemical estrogen receptor detection (ERICA) in breast cancer tissue]. Pathologe. 1987; 8(3):138140.

34. Pages F, Berger A, Camus M, Sanchez-Cabo F, Costes A, Molidor R, Mlecnik B, Kirilovsky A, Nilsson M, Damotte D, Meatchi T, Bruneval P, Cugnenc PH, Trajanoski Z, Fridman WH and Galon J. Effector memory T cells, early metastasis, and survival in colorectal cancer. N Engl J Med. 2005; 353(25):2654-2666. 